\title{
Isolation of (S)-1, cis-5-Undecadien-3-ol, a Possible Precursor of Male-Gamete Attractants from Dictyopteris undulata
}

\author{
Tadahiko KaJIWARA, ${ }^{* 1}$ Kazuya Kodama, ${ }^{* 2}$ and Akikazu HatanaKA*1 \\ (Received July 20, 1981)
}

\begin{abstract}
Dictyoprolenol, properly named $(S)$-1, cis-5-undecadien-3-ol, which was postulated as a possible precursor of male-gamete attractants by MOoRE et al., was isolated from Dictyopteris undulata. Dicytoprolene was not detected in $D$. undulata and $(S)$-1, cis-5-undecadien-3-ol was not detected in $D$. prolifera. This discrepancy is probably due to a difference in the acylesterase activities of $D$. undulata and $D$. prolifera.
\end{abstract}

Non-isoprenoids $\mathrm{C}_{11}$-hydrocarbons such as dictyopterene A (1), B (2), $\mathrm{C}^{\prime}$ (3) and $\mathrm{D}^{\prime}$ (4) have been isolated from Hawaiian ${ }^{1-B)}$ and Japanese Dictyopteris. $^{7-8)}$ On the other hand, $\mathrm{C}_{11}$-olefins, dictyopterene $\mathrm{D}^{\prime}$ or ectocarpene (4), multifidene (5) and $\mathrm{C}_{8}$-olefin, fucoserratene (6), have been identified as male-gamete attractants of brown marine algae, Ectocarpus, ${ }^{4)}$ Cutleria ${ }^{8)}$ Fucus $^{10)}$ and Sargassum, ${ }^{11,12)}$ respectively. MoORE ${ }^{13)}$ and $\mathrm{JAENICKE}^{14)}$ have proposed an attractive hypothesis that these hydrocarbons $(1-6)$ are biosynthesized via $(S)$-1, cis-5-undecadien-3-ol (7) and $(S)$-1, cis-5, cis-8-undecatrien-3-ol (8), from linoleic and linolenic acids, respectively as shown in Fig. 1. Recently, YAMADA et al. ${ }^{7,87}$ have reported isolation of the acetates of $\mathbf{7}$ and $\mathbf{8}$, dictyoprolene and neodictyoprolene, from Dictyopteris prolifera.

This paper describes the isolation and structure determination of 7 from $D$. undulata.

\section{Meterials and Methods}

IR spectra were taken by a Hitachi EPI-G2 spectrometer using a potassium bromide disk. PMR spectra were obtained with a Hitachi PerkinElmer R-24 spectrometer in $d$-chloroform or $\mathrm{CCl}_{4}$ containing TMS as an internal reference. ${ }^{18} \mathrm{C}$ NMR spectra were measured with $d$-chloroform on a JEOL JNM-FX 100 spectrometer. Mass specta were afforded with a Shimadzu LKB-9000 at $70 \mathrm{eV}$. Optical rotations were measured on a JASCO DPI-SL automatic polarimeter. Analytical and preparative GLC were performed on a Shimadzu GC-6A and a Varian 920 gas chroma- tography, respectively: $5 \%$ PEG $20 \mathrm{M} 1 \mathrm{~m} \times 5 \mathrm{~mm}$, column temp. $170^{\circ} \mathrm{C}$, flow rate $40 \mathrm{ml} / \mathrm{min}$. (condition-a); $15 \%$ DEGS $3 \mathrm{~m} \times 5 \mathrm{~mm}$, column temp. $80^{\circ} \mathrm{C}$, flow rate $50 \mathrm{ml} / \mathrm{min}$. (condition-b); $20 \%$ PEG $20 \mathrm{M}$ glass capillary column $20 \mathrm{~m} \times 0.25 \mathrm{~mm}$, column temp. $130^{\circ} \mathrm{C}$, flow rate $50 \mathrm{ml} / \mathrm{min}$. (condition-c); FFAP glass capillary column $40 \mathrm{~m} \times$ $0.3 \mathrm{~mm}$, column temp. $150^{\circ} \mathrm{C}$, flow rate $60 \mathrm{ml} / \mathrm{min}$. (condition-d); $5 \%$ PEG 20M $3 \mathrm{~m} \times 3 \mathrm{~mm}$, column temp. $150^{\circ} \mathrm{C}$, flow rate $60 \mathrm{~m} 1 / \mathrm{min}$ (condition-e).

Dictyopteris undulata and Dictyopteris prolifera were collected along Usa coast, Kochi, Japan in August, 1980 and at Shimonoseki, Yamaguchi, Japan in June 1980, respectively.

Isolation and Identification of (S)-1, cis-5-Undecadien-3-ol

The freshly collected, wet $D$. undulata $(2.1 \mathrm{~kg})$ was digested in acetone $(4 l)$ for 4 days and the solvent of the extract was evaporated in vacuo. The residual oil $(3 \mathrm{~g})$ was introduced onto a $2 \times$ $30 \mathrm{~cm}$ column of silica gel and the chromatogram was developed with a mixed solvent of benzene and hexane: $50 \mathrm{ml}$ of $10 \%$ benzene-hexane, $50 \mathrm{ml}$ of $20 \%$ benzene-hexane, $50 \mathrm{ml}$ of $30 \%$ benzenehexane and $50 \mathrm{ml}$ of $40 \%$ benzene-hexane $(1 \mathrm{~g}$ of essential oil). The essential oil in hexane was silica gel column $(1.7 \times 16 \mathrm{~cm})$ chromatographed using $25 \mathrm{ml}$ of hexane, $25 \mathrm{ml}$ of $35 \%$ benzenehexane (sesquiterpens), $25 \mathrm{ml}$ of $65 \%$ benzenehexane, $25 \mathrm{ml}$ of benzene and $35 \%$ ether-benzene (60 mg of alcohol). The crude alcohol was florisil column $(1 \times 14 \mathrm{~cm})$ chromatographed using $18 \mathrm{ml}$ of hexane, $12 \mathrm{ml}$ of $25 \%$ ether-hexane

*1 Department of Agricultural Chemistry, Faculty of Agriculture, Yamaguchi University, Yamaguchi 753, Japan (椐原忠炇中顕和：山上大学農学部農芸化学科).

*2 Research Laboratory, Kaken Drug Co., Ltd., Mitaka, Tokyo 181, Japan (小王一哉: 化研生藻). 


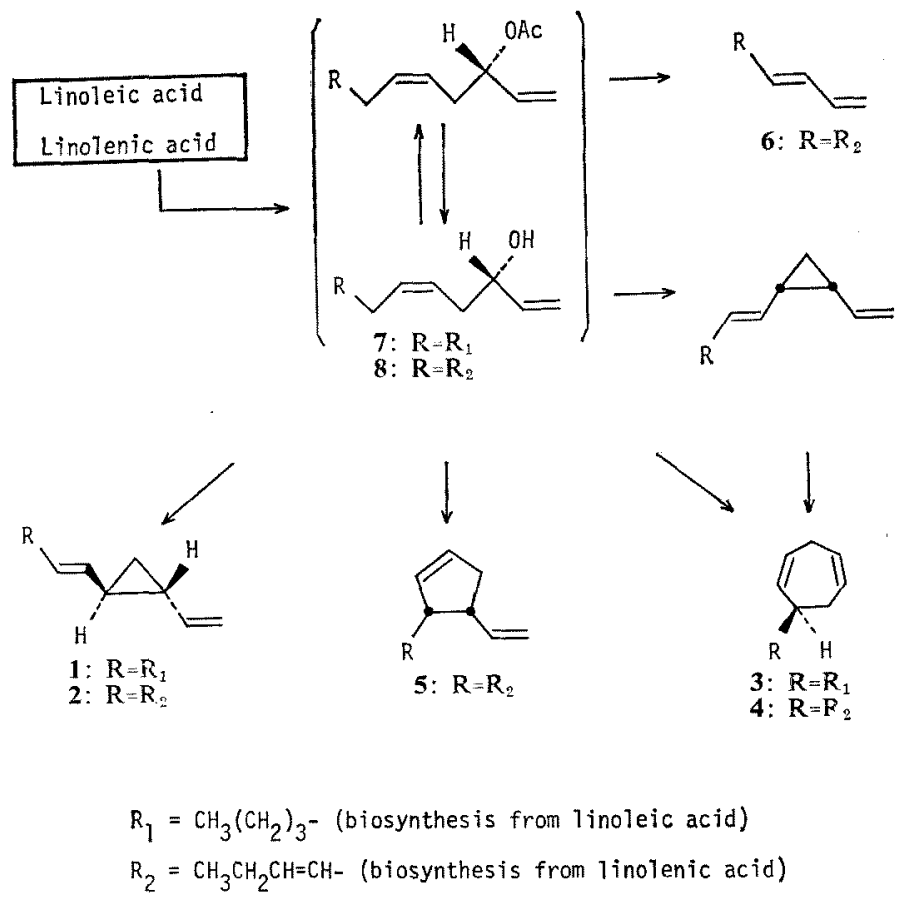

Fig. 1. Hypothesis of biogenetic pathway of male-gamete attractants of marine brown algae.

(methyl ester of fatty acid) and $12 \mathrm{ml}$ of $65 \%$ ether-hexane (18 $\mathrm{mg}$ of $\mathrm{C}_{11}$-alcohol). The $\mathrm{C}_{11}$ alcohol fraction was rechromatographed: $3 \mathrm{ml}$ of $35 \%$ dichloromethane-hexane, $3 \mathrm{ml}$ of $50 \%$ dichloromethane-hexane and $8 \mathrm{ml}$ of $65 \%$ dichloromethane-hexane ( $9.4 \mathrm{mg}$ of pure $\mathrm{C}_{11}$-alcohol).

\section{Isolation of Dictyoprolene}

The freshly collected, wet Dictyopteris prolifera $(10.5 \mathrm{~kg})$ was digested in acetone $(18 l)$ twice and the extract was concentrated under reduced pressure. The concentrate $(90 \mathrm{~g})$ was introduced on silica gel (for dry column chromatography: $1 \mathrm{~kg}$ ) column. Elution with $3 l$ of $20 \%$ benzenepentane gave $8.2 \mathrm{~g}$ of odoriferous oil. The oil was florisil $(50 \mathrm{~g})$ column chromatographed: $180 \mathrm{ml}$ of pet. ether $(5.5 \mathrm{~g}$, fraction-1); $400 \mathrm{ml}$ of $10-80 \%$ benzene-pet. ether $(0.1 \mathrm{~g}) ; 200 \mathrm{ml}$ of $90-100 \%$ benzene-pet. ether $(1.2 \mathrm{~g}$, fraction- 2$)$; $150 \mathrm{ml}$ of $10-30 \%$ ether-benzene $(58 \mathrm{mg}$ of triglyceride). Fraction-2 was rechromatographed on florisil: elution with $85 \mathrm{ml}$ of $30 \%$ etherhexane gave $400 \mathrm{mg}$ of crude acetate which was separated to three fractions by preparative GLC (condition-a): fraction-a $(3.5 \mathrm{~min}$, dictyoprolene $45 \mathrm{mg}$ ), fraction-b ( $8.5 \mathrm{~min}$ methyl ester of fatty acids) and fraction-c (15 min, unknown $5.3 \mathrm{~g}$ ).
Fraction 1 was distilled to afford $\mathrm{C}_{11}$-hydrocarbons (bp. $78-80^{\circ} \mathrm{C} / 15 \mathrm{mmHg}$ ) which was chromatographed on $25 \%$ silver nitrate-silica gel: $100 \mathrm{ml}$ of $5 \%$ ether-hexane (fraction $3700 \mathrm{mg}$ ) and $100 \mathrm{ml}$ of $10 \%$ ether-hexane (dictyopterene B $80 \mathrm{mg}$ ). Fraction 3 was separated into dictyopterene $C^{\prime}$ $(20 \mathrm{mg})$, dictyopterene $\mathrm{D}^{\prime}(20 \mathrm{mg})$ and dictyopterene A ( $300 \mathrm{mg}$ ) by preparative GLC (condition-b).

Conversion of 1,5-cis-Undecadien-3-ol to Dictyoprolene

Fresh $D$. prolifera $(10 \mathrm{~g})$ were blended with $\mathrm{H}_{2} \mathrm{O}(10 \mathrm{ml})$ for $3 \mathrm{~min}$ and the homogenate thus obtained was incubated with 1,5-cis-undecadien3-ol $(10 \mu \mathrm{l})$ at $35^{\circ} \mathrm{C}$ for $10 \mathrm{~min}$. The reaction mixture was extracted with ether $(50 \mathrm{ml} \times 3)$ and the solvent was evaporated in vacuo. The concentrate was analyzed by GLC (condition-e) using authentic dictyoprolene $(8.6 \mathrm{~min})$ and 1 , cis-5undecadien-3-ol (10.3 $\mathrm{min}$ ).

\section{Results and Discussions}

The fresh wet $D$. undulata $(2.1 \mathrm{~kg})$ were soaked in acetone and the acetone soluble extract was concentrated in vacuo to yield a brown oil, which was chromatographed on silica with $40 \%$ benzene- 
Table 1. ${ }^{1} \mathrm{H}-\mathrm{NMR}$ and ${ }^{13} \mathrm{C}-\mathrm{NMR}$ data of dictyoprolenol from $D$. undulata

\begin{tabular}{|c|c|c|c|}
\hline \multirow{2}{*}{$\begin{array}{c}\text { Carbon } \\
\text { No. }\end{array}$} & ${ }^{13} \mathrm{C}-\mathrm{NMR}$ & \multicolumn{2}{|c|}{${ }^{1} \mathrm{H}-\mathrm{NMR}$} \\
\hline & $\delta(\mathrm{ppm})$ & \multicolumn{2}{|c|}{$\delta(\mathrm{ppm})$, Multiplicity, $\mathbf{J}(\mathrm{Hz})$} \\
\hline \multirow[t]{2}{*}{1} & 114.7 & $4.95 \mathrm{dt}$ & 10,2 \\
\hline & & $5.26 \mathrm{dt}$ & 17,2 \\
\hline 2 & 140.5 & $5.81 \mathrm{ddd}$ & $17,10,6$ \\
\hline 3 & 72.5 & $4.01 \mathrm{q}$ & 6 \\
\hline 4 & 35.0 & $2.19 \mathrm{t}$ & 6 \\
\hline 5 & $124.2^{*}$ & & \\
\hline 6 & $133.8^{*}$ & $5.30 \mathrm{~m}$ & \\
\hline 7 & 27.4 & $2.01 \mathrm{q}$ & 6 \\
\hline 8 & 29.3 & & \\
\hline 9 & 31.5 & $1.26 \mathrm{~m}$ & \\
\hline 10 & 22.5 & & \\
\hline 11 & 14.0 & $0.88 \mathrm{t}$ & 6 \\
\hline$-\mathrm{OH}$ & - & $1.50 \mathrm{~s}$ & \\
\hline
\end{tabular}

Table 2. Formation of dictyoprolene from dictyoprolenol by the homogenate of $D$. prolifera

\begin{tabular}{lc}
\multicolumn{1}{c}{$\begin{array}{c}\text { Substrate } \\
(10 \mu \mathrm{l})\end{array}$} & $\begin{array}{c}\text { Dictyoprolene* } \\
\text { produced }\left(\mathrm{mm}^{2}\right)\end{array}$ \\
\hline None & trace \\
1,5 -cis-undecadien-3-ol & 60 \\
1,5 -cis-undecadien-3-ol & 320 \\
$+\mathrm{AcOH}(6 \mu \mathrm{l})$ & \\
\hline 10 $\mu \mathrm{l}$ of concentrate $(1 \mathrm{ml})$ of reaction mixture was analyzed by \\
GLC as given in Materials and Methods. Chirotopical data of \\
the product, dictyoprolene, have not been obtained.
\end{tabular}

hexane, to give an odoriferous oil $(1 \mathrm{~g})$. The oil was found to be a mixture of sesquiterpenes ${ }^{\theta)}$ ( $\alpha$-copaene: $2 \% 15.5 \mathrm{~min}, \beta$-cubebene; 7\% 16.7 min, $\delta$-cadinene $60 \% 21.7 \mathrm{~min}$ and unknown $20 \%$ ) and $\mathrm{C}_{11}$-hydrocarbons ${ }^{2)}(1 ; 6 \% 7.3 \mathrm{~min}, 3 ; 2 \%$ $8.1 \mathrm{~min}, 4 ; 0.3 \% 8.3 \mathrm{~min}, 2 ; 2 \% 9.3 \mathrm{~min}$ and unknown $0.7 \%$ ) accompanied by a samll amount of alcohol by capillary GLC (condition-c) and MS analyses. Chromatography of the crude alcohol on florisil (hexane and increasing amount of diethyl ether) gave fairly pure alcohol $(18 \mathrm{mg})$, which was rechromatographed on florisil to give $9.4 \mathrm{mg}$ of $(S)$-1, cis-5-undecadien-3-ol (7); $[\alpha]_{\mathrm{D}}+$ $3.7^{\circ}(\mathrm{c}, 0.16) ; \mathrm{MS} \mathrm{m} / \mathrm{z}(70 \mathrm{eV}): 168\left(\mathrm{M}^{+}, 0.08 \%\right.$, $150\left(\mathrm{M}^{+}-18,0.8 \%\right), 84(13 \%), 83(24 \%), 70(37 \%)$, $69(35 \%), 67(8 \%), 57$ (base peak), $56(31 \%), 55$ $(48 \%), 54(12 \%), 43(12 \%), 42(11 \%), 41(47 \%)$, $29(17 \%), 19(39 \%), 18(12 \%), 17(19 \%) ;$ IR (neat) $3400,3080,3000,1840,1640\left(\mathrm{~cm}^{-1}\right)$. The structure of 7 was fully substantiated by comparison of ${ }^{1} \mathrm{H}-\mathrm{NMR}$ and ${ }^{18} \mathrm{C}$-NMR data with those of authentic (土)-7*3 and its acetate as indicated in Table 1. Acetylation $\left(\mathrm{Ac}_{2} \mathrm{O}\right.$-pyridine, room temp. $12 \mathrm{hr}$ ) gave an acetate $[\alpha]_{\mathrm{D}}+13.0^{\circ}$ (c, 0.11); ${ }^{1} \mathrm{H}-\mathrm{NMR}\left(\mathrm{CDCl}_{\mathrm{g}}\right) \delta 0.87(\mathrm{t}, 3 \mathrm{H}, \mathrm{J}=6)$, $1.28(\mathrm{~m}, 6 \mathrm{H}), 2.06(\mathrm{q}, 2 \mathrm{H}, \mathrm{J}=6), 2.30(\mathrm{t}, 2 \mathrm{H}$, $\mathrm{J}=6), 4.92-5.33(\mathrm{~m}, 5 \mathrm{H}), 5.72(\mathrm{ddd}, 1 \mathrm{H}, \mathrm{J}=17$, 10, 6) COMe $1.98(\mathrm{~s}, 3 \mathrm{H}) ;{ }^{18} \mathrm{C}-\mathrm{NMR} \delta 14.1,22.6$, $27.2,29.2,31.4,32.2,74.2,116.7,123.5,133.1$, 136.2, COMe 21.1, $\mathrm{C}=0$ 170.1; MS m/z (70 eV): $150\left(\mathrm{M}^{+}-\overline{\mathrm{AcOH}}, 3 \%\right), 99(19 \%), 79(10 \%), 43$ (base peak); IR (neat) 3080, 3000, 1740, 1640 $\left(\mathrm{cm}^{-1}\right)$; GLC data (condition-d): undecadien-3-ol $31.5 \mathrm{~min}$; its acetate $26.0 \mathrm{~min}$, which was identified with natural dictyoprolene. Thus the absolute configuration of dictyoprolenol (7) should be $(S)$.

On the other hand, an odoriferous oil from fresh wet $D$. prolifera was chromatographed on florisil with benzene-petroleum ether to give an essential oil (fraction-2). Fraction 2 was rechromatographed on florisil (hexane and increasing amount of diethyl ether) to afford an odoriferous oil which was separated into three fractions by preparative GLC (condition-a); dictypoprolene ( $3.5 \mathrm{~min}, 45 \mathrm{mg}$ ), methyl ester of fatty acids and unknown compounds.

In $D$. undulata, dictyoprolene, the acetate of dictyoprolenol (7), was not detected and 7 not detected in $D$. prolifera. This discrepancy is probably due to acylesterase activities producing dictyoprolene from the corresponding alcohol in D. prolifera, as shown in Table 2. The increase of dictyoprolene was observed in addition of synthetic 1, cis-5-undecadien-3-ol to homogenates of $D$. prolifera. When the substrates were added to the heat-denatured homogenate, the alcohol was not converted to the corresponding acetate, dictyoprolene. Experiments on seasonal changes of the acylesterase activities and isolation of 1 , cis-5, cis-8-undecatrien-3-ol (8) are in progress.

\section{Acknowledgements}

The authors would like to express their thanks to Dr. M. OHNo, Usa Marine Biological Station, Kochi University, Usa Japan, for identifying and collecting algae and Miss M. NAwATE, Yamaguchi University for her skilled technical assistance. Financial support from the Ministry of Education

*3 The tetrahydropyran derivative of hex-1-en-5-yn-3-ol was converted into the sodium salt and then alkylated with amyl bromide. ${ }^{15}$ Hydrolysis of the resulting THP derivative of undeca-1-en-5-yn-3-ol with methanolic $\mathrm{TsOH}$ followed by catalytic hydrogenation afforded racemic 7 . 
Science, and Culture (Grant-in Aid for Scientific Research No. 556092) is gratefully acknowledged.

\section{References}

1) R. E. Moore, J. A. Pettus, JR., and M. S. Doty: Tetrahedron Lett., 4787-4790 (1968).

2) J. A. Pettus, JR. and R. E. Moore: Chem. Comm., 1093-1094 (1970).

3) J. A. Petrus, JR, and R. E. Moore: J. Am. Chem. Soc., 93, 3087-3088 (1971).

4) D. G. Müller, L. Jaenicke, M. Donike, and T. Akintobi: Science, 171, 815-817 (1971).

5) R. E. Moore, J .A. Pettus, JR., and J. Mistysyn: J. Org. Chem., 39, 2201-2207 (1974).

6) L. J JeNICKE, D. G. MüLler, and R. E. MoORE: J. Am. Chem. Soc., 96, 3324-3325 (1974).
7) K. Yamada, H. Tan, and H. Tatematsu: Chem. Comm., 572-573 (1979).

8) K. Yamada, M. OJIKA, and H. TAN: Chem. Lett., 1633-1634 (1980).

9) T. Kajiwara, K. Kodama, and A. Hatanaka: Bull. Japan. Soc. Sci. Fish., 46, 771-775 (1980).

10) D. G. MüLLER and L. JAENICKE: FFBS Lett., 30, 137-139 (1973).

11) T. Kajiwara, K. Kodama, and A. Hatanaka: Bull. Japan. Soc. Sci. Fish, 46, 555-557 (1980).

12) T. Kajwara, K. Kodama, and A. Hatanaka: Naturwissenschaften, 67, 612-613 (1980).

13) R. E. Moore: Lloydia, 39, 181-191 (1976).

14) L. JAENICKE: Naturwissenschaften, 64, 69-75 (1977).

15) A. Vrola and J. H. MacMillan: J. Am. Chem. Soc., 90, 6141-6145 (1968). 